\title{
Participation of micromycetes and bacteria in joint humification waste of wood breed
}

Sviridova O.V. ${ }^{1}$, Vorobyov N.I. ${ }^{1}$, Puhalsky Y.V. ${ }^{1,2}$, Orlova O.V. ${ }^{1}$, Popov A.A. ${ }^{1}$, Mityukov A.S. ${ }^{4}$, Laktionov Yu.V. ${ }^{1}$, Pishchik V.N. ${ }^{1,3}$

${ }^{1}$ All-Russian Research Institute for Agricultural Microbiology, Saint-Petersburg, Russian

Federation, juan_diego@humic.edu

${ }^{2}$ Scientific Production Association «BioEcoTech LTD», Saint-Petersburg, Russian Federation

${ }^{3}$ Agrophysical Research Institute, Saint-Petersburg, Russian Federation

${ }^{4}$ Limnology Institute of Russian Academy of Sciences, Saint-Petersburg, Russian Federation

doi: 10.36291/HIT.2019.sviridova.081

The processes of microbiological humification of bark of coniferous trees at two levels of mineral fertilizers with using of biological preparation Barkon developed in the ARRIAM (Saint Petersburg, Russia) were studied. The dominated microorganisms in Barkon were mycromycetes Penicillium chrysogenum (Thom 1910) OH 4 RCAM 00741 and bacteria Pseudomonas fluorescens 7RCAM 00537. The composition of the biopreparation included micromycetes, cellulolytic and nitrogen-fixing bacteria, and lignin decomposers bacteria (Sviridova et al., 1993). The biochemical conversion processes in compost occurred with the close interaction of micromycetes from genus Pennicilium and Pseudomonas fluorescens bacteria in a self-organizing biosystem (Fig.1). As it was shown by factor analysis, the micromycetes in this biosystem mainly destructed of polymer organic molecules of lignocellulose, due to the presence in them of oxidoreductases (Vedenyapina et al. 2010). The absence of an optimal organization of humification processes was revealed without the use of a biopreparation indicates

The optimal technological conditions for composting wastes of coniferous wood using nitrogen fertilizers and biopreparation - Barkon have been identified. As a result of composting obtained an organic fertilizer. This fertilizer was tested on phytotoxicity. It was fixed that the fertilizers studied do not possess phytotoxic activity and inhibit the development of phytopathogenic micromycetes Fusarium oxysporum.

3

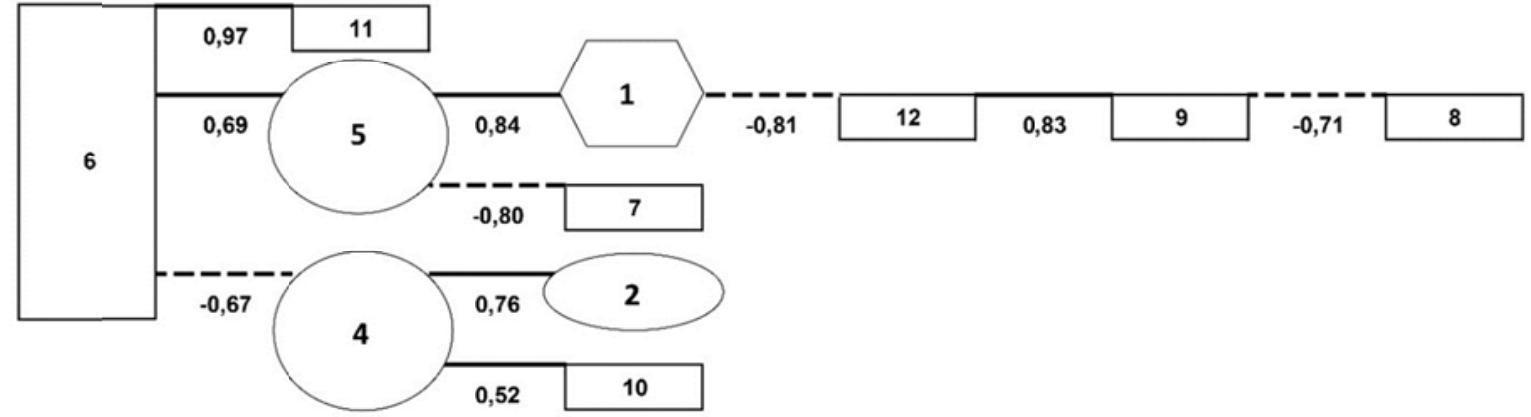

Figure 1. A graph of the maximum correlation coefficients between the biochemical characteristics of compost and the microbiological composition of the biosystem during the destruction of sawdust conifers trees. Note: Numbers correspond the designations: 1 micromycetes (cells), 2 - proteolytic bacteria (cells), 3 - amylolytic bacteria (cells), 4 lignin decomposers bacteria(cells), 5 - cellulolytic bacteria (cells), $6-\mathrm{N}_{\text {total }}, 7-\mathrm{N}-\mathrm{NO}_{3}, 8$ $\mathrm{C}_{\text {org }}, 9$ - level of humification of compost, $10-\mathrm{C}_{-} \mathrm{CO}_{2}, 11$ - using/unusing of $\mathrm{N}(1 / 0), 12-$ using/unusing of a biopreparation (1/0).

This work was supported by a subsidy of the Ministry of Education and Science of the Russian Federation № 14.607.21.0178, unique identifier of the agreement: RFMEFI60717X0178. 